\title{
The Role of Human Resource Quality in Mediating Human Resource Management, Information Technology and Organisational Culture on Employee Performance: A Study on Indonesian E-Commerce Industry
}

\author{
William Widjaja $^{{ }^{*} \text {, Syamsul Maarif }}{ }^{2}$, Edie Toet Hendratno ${ }^{3}$, Widarto Rachbini ${ }^{4}$ \\ ${ }^{1}$ Retail Management Department, Undergraduate Program, Pradita University, Indonesia \\ ${ }^{2}$ Management Department, Graduate School, IPB University, Indonesia \\ ${ }^{3,4}$ Management Department, Graduate School, Pancasila University, Indonesia
}

\begin{abstract}
*Corresponding Author: William Widjaja, Retail Management Department, Undergraduate Program, Pradita University, Indonesia
\end{abstract}

\begin{abstract}
E-commerce growth continues to make a positive contribution to Indonesia's economic growth over time. However, unfortunately, the e-commerce business's growth has not been balanced with adequate human resources (HR). Besides, the quality of human resources is also needed to encourage performance to improve their competitiveness.This study aims to analyse human resource management, information and technology, and organisational culture that can drive human resource (HR) quality and employee performance. This research is ex post facto with a survey method with a quantitative approach. The instrument used was a questionnaire distributed to 200 employees in the e-commerce industry. The sampling technique uses non-probability sampling with a purposive sampling method. Data analysis techniques used structural equation modelling (SEM) analysis.SEM analysis results show that HR management, information technology, and organisational culture significantly influence HR quality and performance both directly and indirectly.
\end{abstract}

Keywords: E-commerce, Employee Performance, Human Resource Management, Human Resource Quality, Information \& Technology, Organisational Culture.

\section{INTRODUCTION}

Many Indonesian e-commerce companies are growing significantly. Based on the data presented by IPrice, many consumers have the potential to shop in Indonesian e-commerce. It can be seen in figure 1 as follows:
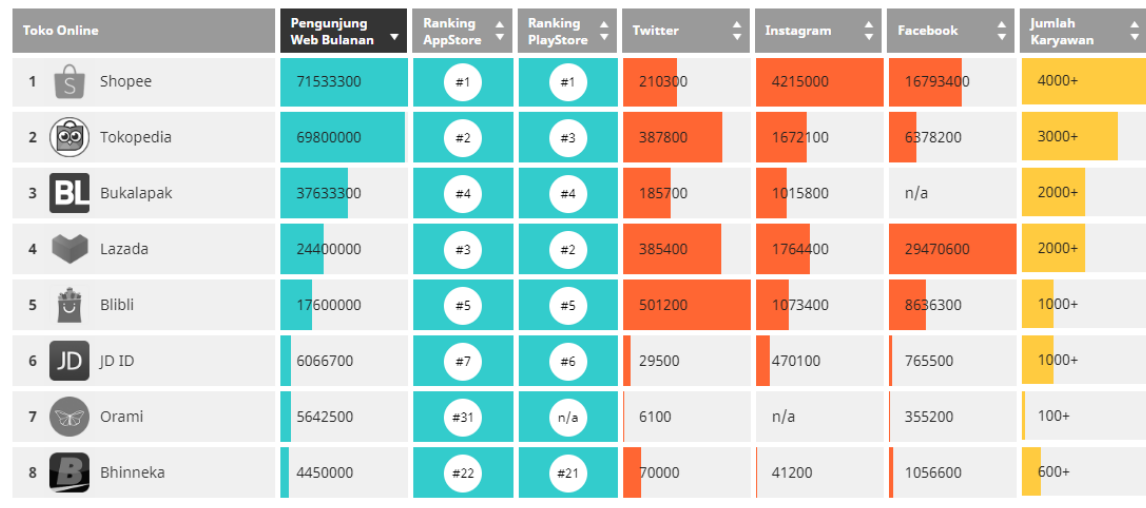

Figure1. Total of Web Visitors

Source: https://iprice.co.id/insights/mapofecommerce/

The e-commerce business can sustain and improve its performance if various aspects support them, such as its human resources performance. Mangkunegara (2015) explains that employee performance results from work in quality and quantity achieved by a person carrying out his duties the responsibilities assigned to him. Hee and Jing (2018) explain that human resources are the most 
The Role of Human Resource Quality in Mediating Human Resource Management, Information Technology and Organisational Culture on Employee Performance: A Study on Indonesian E-Commerce Industry

critical component in moving business organisations towards profitability. In addition to maintaining and improving organisational performance, HR performance can also drive corporate competitive advantage or commonly called competitive advantages (Diamantidis\&Chatzoglou, 2018). So it can be concluded that employee performance is an essential factor in maintaining and improving organisational performance and maintaining e-commerce companies' competitiveness.

Unfortunately, the significant growth of e-commerce has not been matched by the quality and readyto-use human resources (HR) needed by this industry. Thaief (2014) stated that the progress of ebusiness is not currently balanced with the readiness of workers in the industry. Likewise, Sudarwati (2017) said that the availability of reliable human resources had not matched the rapid growth of ebusiness in Indonesia. It has made Indonesia's digital competitiveness ranked in the fifth lowest in the world. Economic coordinating ministry data shows that $60 \%$ of the workforce generally fill jobs as administrative staff, and $60 \%$ of this number is dominated by junior high school graduates (AR, 2019). Besides, based on a survey conducted by iPrice Indonesia, it was explained that at least many e-commerce companies had difficulty recruiting expert professionals for certain parts, such as software engineering, digital marketing, data science, and product marketing. It is, of course, due to the absence of an adequate supply of experts in this field. So it can be concluded that Indonesia needs to improve both the quantity and quality of human resources, especially in the e-commerce industry.

All organisations or companies, including the e-commerce industry, can continue to advance and exist if they have quality human resources. By having quality human resources, the company's performance will be maximised and achieved success (Runtu, Mandey, \&Ogotan, 2015) and completeits vision, mission and goals (Raymond, Hatane, \&Hutabarat, 2015). Quality human resources are human resources with abundant mindsets, rich in knowledge and skills (excellent skillsets), and good character (ample heart sets). Qualified human resources are human resources that have competencies that refer to three aspects, namely knowledge, skills (hard skills) and behaviour (soft skills) such as loyalty, discipline, collaboration, responsibility (Alfiyah, 2016).

In an organisation, HR management is the primary responsibility of the human resource management function (HRM), starting from recruitment and selection, training and development, performance evaluation, promotion to remuneration (Abdoulaye, 2018). Humans are difficult to manage due to their complexity to impact their work within the organisation (Ayangbekun\&Olowookere, 2014). Therefore, HR practice in an organisation is an essential function to pay attention to which HRM practices can shape and improve HR's quality (Zuraida, Gustomo, Bekti, \&Pangestu, 2017). Besides being able to improve the quality of HR and HRM is also able to improve employee performance. (Tabouli, 2016; Rumasukun, 2015).

The development of information technology (IT) has changed business and HR practices and policies. IT has also had a positive impact on organisational functions (Zahra, 2013). In line with Zahra, Elhazzam (2015) explains that technology positively impacts HR management functions and the organisation. Technology has become a tool that makes work effective and efficient for its users. However, sometimes the technology currently present cannot be fully utilised by its users, so competencies in the IT field need to be continuously developed (Subair, 2008). In fact, in the next ten years, at the macro level, 60 per cent of the workforce needs to be retrained in skills and expertise (reskilling). Many human resources do not have the competencies needed for industry 4.0 (Rahadian, 2019).

Besides HRM and technology and information, organisational culture is also crucial in creating quality human resources. Corporate culture can encourage human resources to continue innovating and adapting to their demands in their work field. The organisation's ability to form a positive organisational culture in the work environment will encourage its human resources to continue to improve the quality of their competencies. Simbolon (2019) and Paus (2018) said a significant influence between organisational culture on employee competence. From these logical and empirical facts, it can be concluded that the performance and quality of human resources in the e-commerce industry need to be continuously improved so that this industry can survive, compete, and make a significant contribution to the digital economy's growth in Indonesia. 
The Role of Human Resource Quality in Mediating Human Resource Management, Information Technology and Organisational Culture on Employee Performance: A Study on Indonesian E-Commerce Industry

\section{LITERATURE REVIEW}

\subsection{Employee Performance}

Wibowo (2016) performance is something that will be done and how to do it. Mangkunegara (2015) describes the performance as a result of work in quality and quantity achieved by an employee in carrying out his duties in accordance with the responsibilities given to him. According to Bangun (2018), performance results from a person's work based on specific requirements to achieve the goal also referred to as the standard of work. So it can be concluded that performance results from work on an effort that a person pours out in achieving the work standards set by the organisation to achieve the organisation's goals. Therefore, companies need to maintain and improve the performance of their employees.

The performance of a software engineer or programmer, according to Sleekr (2019), can be measured through: Create programs for the needs of the company, Generate programs from the collaboration of business analysts and developers, Formulate program specifications and basic prototypes, Transform software design and specifications into high functioning code following the programming language, Update or repair thesoftware used, Perform service error complain, Monitor the software database, Perform downtime tasks of the application server. Ahmed et al. (2013) added that in addition to technical performance, a programmer also needs to be measured performance based on soft performance consisting of:Accept openness and adapt to change, Work independently, Work in teams, ability to organise, Interpersonal skills, Communication skills. Based on the explanation, the performance of employees in the e-commerce industry can be mapped as follows:

\subsection{Human Resource Quality}

Mulyana (2010) describes quality as the conformity of standards with the results achieved, while human resources integrate the ability to think and the physical condition that a person has (Hasibuan, 2016). Wirawan (2015) and Soegoto (2014) explained that human resourceworks for an organisation that contributes value to its achievement.

Qualified human resources can be measured through their qualifications and competencies (Sunhaji, 2014). Wibowo (2016) explained that competence is a person's ability to complete his duties and responsibilities based on knowledge, skills, and attitudes needed in his work. In line with Makulova et al. (2015) argues that competence is the ability that a person has to do a job based on life experience and knowledge and skills that he has. Spencer (2014) also explained that competence is the skills and abilities possessed and gained through work experience, life experience, education, and training. So it can be concluded that competence is a combination of knowledge, experience, skills, attitudes used and obtained to complete tasks and responsibilities.

Patacsil and Tablatin (2017) further explained that an IT or programmer needs to master some hard and soft competencies. Hard competencies consist of knowledge of standard software applications such as operating systems and application software.Knowledge of programming languages such as HTML, PHP, JavaScript, C++, Visual Basic.Ability to design software to be user friendly and display a variety of information that will be represented geographically (GIS or Geographic Information System).Knowledge of databases such as JSON, XML, MySQL, MongoDB, Oracle, knowledge of networks such as LAN, MAN, WAN, Internet and VPN.Knowledge of computer hardware such as motherboard, CPU, GPU, VGA, memory, hard disk, and others.

\subsection{Human Resource Management}

According to Dessler (2017), human resource management (HRM) is the process of acquiring, train, assess, and compensate employees and taking care of labour relations, health and safety, and matters related to justice. Mathis et al. (2016), HRM can be interpreted as a science and art that regulates the workforce's relationship and role to be effective and efficient in using human capabilities to achieve goals in each company. Based on experts' definition, it can be concluded that HR management is a process of HR management ranging from recruitment and pensions oriented to efficiency and effectiveness to achieve organisational goals. 
The Role of Human Resource Quality in Mediating Human Resource Management, Information Technology and Organisational Culture on Employee Performance: A Study on Indonesian E-Commerce Industry

According to Hong et al. (2012), human resource management can be measured based on its function. Compensation is financial or non-financial appreciation obtained by employees to sacrifice time, energy, risk, knowledge, skills, and other things to the company. Training and development is a systematic and planned activity to improve employees' knowledge, skills, and behaviour in carrying out their duties to comply with the expected standards and improve the performance of those employees. The assessment system is a process of examining and evaluating an employee's performance that will be used as the basis for awarding, such as; promotion. Retaining Employees is a company policy used to keep its best employees working in the company.

Shaukat et al. (2015) and Marwat et al. (2006) argue that in addition to these four functions,human resource management can also be measured by selection is the initial effort of a company in obtaining competent employees. Following the qualifications required by the company's position or job, Career Planning is a system built to create satisfaction of work, fairness, and objectiveness towards employees, especially for their career development in the company. Employee Participation is an opportunity and positive response that the company gives to its employees to provide input or new ideas for its progress.The definition of work is a combination of work description with working specifications. The definition of work clearly explains the work, responsibilities, working conditions, and skills that a person needs in completing his/her work.

\subsection{Information and Technology}

Information technology is the study or use of electronic equipment, especially computers, to store, analyse, and distribute any information, including number words and images (Kadir, 2014). Information technology can also be interpreted as a study, design, development, implementation, support, or management of computer-based information systems. IT utilises electronic computers and computer software to securely transform, store, protect, process, transmit and obtain information (Sutarman, 2012). It can be concluded that information technology is a technology used to obtain, transmit, process, interpret, store, and communicate computer-based information.

There are at least a few aspects that can be used in measuring information technology. According to Ravichandran and Lertwongsatien (2005), aspects of information technology infrastructure have an essential role in maintaining a system's capabilities. Good information technology infrastructure can be seen from the platform, data and applications. The platform is an architecture of a combination of hardware and software to run an application. In contrast, data and applications are the company's connectivity, speed, capacity, and platform.

According to Jacob (2013) said that information technology has several indicators. Convenience can make transactions anywhere and anytime. Financial transactions can be done in just a matter of minutes.Risk is not always a bad thing. The reality of ordinary risk contains a massive opportunity for those who manage it well. Trust is the trust of information technology users in deciding the acceptance of information technology. One trust that the user of the information technology can provide a positive contribution to its users.

\subsection{Organisational Culture}

Organisational culture is a habit that has been long-standing and used and applied in the life of work activities as one of the drivers to improve the quality of work of employees and managers of the company (Fahmi, 2013). Organisational culture is a set of values, assumptions, and standards of behaviour that develop and is believed by most members of the organisation as a reference in running the organisation or solving organisational problems, either internally (improving effectiveness, efficiency, and integration) or facing external problems (Badeni, 2013). Organisational culture is a system of meaning-sharing conducted by members that distinguish an organisation from another (Robbins \& Judge, 2015). Organisational culture is a form of beliefs, basic assumptions, values, norms of behaviour, ideology, attitudes, habits, and expectations held by the organisation represented through its behaviour and actions (Rahmi, 2014). Based on the experts' defining, it can be concluded that the organisation's culture is an ideology, values, norms, habits owned and believed by the organisation in carrying out its activities to achieve its goals. 
The Role of Human Resource Quality in Mediating Human Resource Management, Information Technology and Organisational Culture on Employee Performance: A Study on Indonesian E-Commerce Industry

According to Robbins and Judge (2015), seven main characteristics can capture the essence of organisationalculture, innovation and risk-taking, attention to detail, result-oriented, people-oriented, team-oriented, aggressive, and stability. This research was conducted on various largest and wellknown e-commerce companies in Indonesia, such as; Tokopedia, Shopee, Bukalapak, and Blibli. Each of these companies has a culture and value instilled in all its members. Organisational culture can be mapped as follows:

Table1. Organisational Culture

\begin{tabular}{|c|c|c|c|c|c|c|c|c|c|c|c|c|c|c|c|c|c|c|c|c|}
\hline \multirow[b]{2}{*}{$\begin{array}{l}\text { BUDAYA ORGANISASI } \\
\text { (Robbin \& Judge, 2016) }\end{array}$} & \multicolumn{3}{|c|}{$\begin{array}{c}\text { TOK OPE DIA } \\
\text { (NAKAM A) }\end{array}$} & \multicolumn{5}{|c|}{ SH OPEE (5W) } & \multicolumn{5}{|c|}{ BUKALAPAK } & \multicolumn{7}{|c|}{ BLIBLI (RE SPE CT) } \\
\hline & 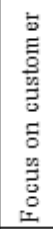 & 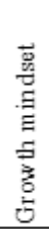 & 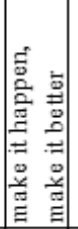 & 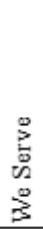 & $\begin{array}{l}\overrightarrow{0} \\
\vec{z} \\
\vec{z}\end{array}$ & $\begin{array}{l}\Xi \\
\Xi \\
\Xi\end{array}$ & $\begin{array}{l}\vec{\Xi} \\
\Xi \\
\vdots \\
ٍ \\
ٍ\end{array}$ & 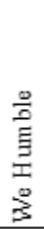 & 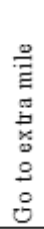 & 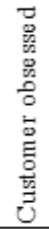 & 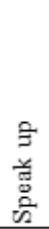 & 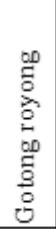 & 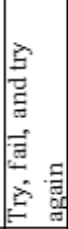 & 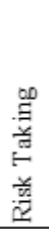 & 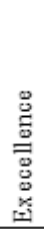 & 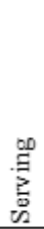 & 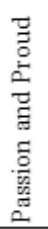 & 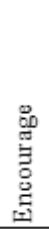 & 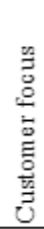 & 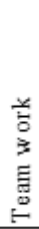 \\
\hline Innovation and Risk Taking & $\mathrm{v}$ & $\mathrm{v}$ & & $\mathrm{v}$ & $\mathrm{v}$ & & & $\mathrm{v}$ & $\mathrm{v}$ & & & & & $\mathrm{v}$ & $\mathrm{v}$ & & & $\mathrm{v}$ & & \\
\hline Attention to Detail & & & $\mathrm{v}$ & & & & $\mathrm{v}$ & & & $\mathrm{v}$ & & & & & $\mathrm{v}$ & & & & & \\
\hline Outc ome orientation & $\mathrm{v}$ & & $\mathrm{v}$ & $\mathrm{v}$ & & & $\mathrm{v}$ & & & $\mathrm{v}$ & & & & & & $\mathrm{v}$ & & & $\mathrm{v}$ & \\
\hline People orientation & & $\mathrm{v}$ & & & & $\mathrm{v}$ & & & & & $\mathrm{v}$ & $\mathrm{v}$ & & & & $\mathrm{v}$ & $\mathrm{v}$ & & & \\
\hline Team orientation & & $\mathrm{v}$ & & & & $\mathrm{v}$ & & $\mathrm{v}$ & & & $\mathrm{v}$ & $\mathrm{v}$ & & & & $\mathrm{v}$ & $\mathrm{v}$ & & & $\mathrm{v}$ \\
\hline Aggressiveness & & & $\mathrm{v}$ & & & & & $\mathrm{v}$ & & & & & $\mathrm{v}$ & & & & & $\mathrm{v}$ & & \\
\hline Sta bility & & & $\mathrm{v}$ & & & & $\mathrm{v}$ & & & & $\mathrm{v}$ & & $\mathrm{v}$ & & & & $\mathrm{v}$ & & & \\
\hline
\end{tabular}

\section{RESEARCH METHODOLOGY}

This research was conducted from February to July 2019 in several e-commerce companies: Tokopedia, Bukalapak, Blibli, Shopee, Ralali and Jakmal. This research is associative research in the form of causal relationships using survey methods and quantitative approaches. The sampling technique used in this study is nonprobability sampling with the purposive sampling method. The respondents' criteria taken as samples are 200 respondents who work in the e-commerce industry, especially in the software engineer or programmer division. The research data collection technique used in this study is to use questionnaires. The analysis technique used is with SEM (structural equation modelling) with SPSS AMOS software.

\subsection{Research Framework}

Based on previous studies and theories, this research model can be described as follows

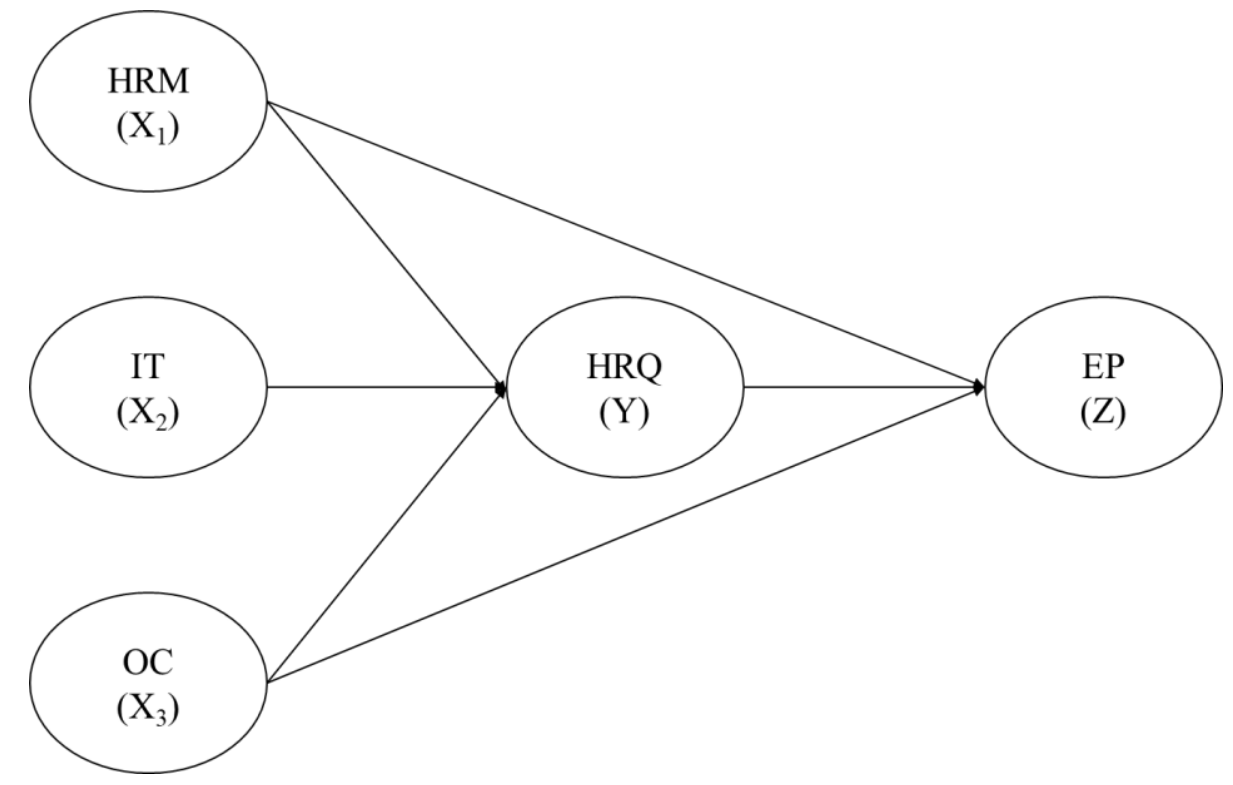

Figure2. Research Framework

Hypotheses are temporary conjectures, which are not yet known to be true. The hypothesis in this study can be formulated as follows: 
The Role of Human Resource Quality in Mediating Human Resource Management, Information Technology and Organisational Culture on Employee Performance: A Study on Indonesian E-Commerce Industry

H1: HR management (HRM) has a significant impact on human resources quality (HRQ).

H2: Information Technology (IT) has a significant impact on human resources quality.

H3: Organizational Culture (OC) has a significant impact on human resources quality.

H4: HR management has a significant impact on employee performance.

H5: The quality of human resources has a significant impact on employee performance (EP).

H6: Organizational Culture has a significant impact on employee performance.

H7: HR management has a significant indirect effect on employee performance through human resources quality.

H8: Information Technology has a significant indirect effect on employee performance through human resources quality.

H9: Organisational culture has a significant indirect effect on employee performance human resources quality.

\section{ANALYSIS AND DiscusSiOn}

\subsection{Descriptive Statistics}

Based on descriptive statistics, employees who are working in the e-commerce industry are dominated by employees with the age range of 24-26 years with a percentage of $67 \%$ and followed by employees with a range of 27-30 (17\%), as well as 20-23 and 31-34 years with a percentage of $8 \%$ each. It shows that most employees working in the e-commerce industry have just graduated from a fresh graduate and productive ages.

From gender, employees who work in the e-commerce industry are mostly men, the percentage of men, $72 \%$ and women $28 \%$ or 72 men and 28 women respectively. It suggests that men tend to be more interested in working as software engineers or programmers in the e-commerce industry. Based on education, employees working in the e-commerce industry are still dominated by a bachelor degree by $75 \%$ and diploma $17 \%$ and Postgraduate as much as $8 \%$. Of the 200 samples taken, most respondents worked at Tokopedia and Shopee with a percentage of 33\% each, followed by employees who worked in Bukalapak, Blibli, Ralali and Jakmal $8 \%$.

Furthermore, judging from the length of work, employees who worked in the e-commerce industry at most within 1-3 years amounted to 58\% or 117 people and followed by less than one year of work as many as 67 people and a working period greater than six years as many as 17 people. Meanwhile, from work experience, the average respondent has 1-3 years work experience as many as 100 respondents, followed by work experience with a range of 4-6 years as many as 67 respondents, $<1$ year and six years with 17 respondents each. Their average income is mostly in the range of 5.1-10 million as many as 117 respondents, followed by income in 10.1-15 million as many as 67 respondents and $>15$ million as many as 17 respondents.

\subsection{Analysis of Results}

Table2. Goodness of Fit

\begin{tabular}{|l|l|l|l|}
\hline Goodness of Fit Index & Estimated Results & Cut off & Keterangan \\
\hline Chi-square / DF & 1.537 & $<3,000$ & fit \\
\hline Probability Level (p) & 0 & $>0,05$ & Not fit \\
\hline Goodness of Index (GFI) & 0,744 & $\geq 0,9$ & Not fit \\
\hline Adjusted Goodness of Index (AGFI) & 0,717 & $\geq 0,9$ & Not fit \\
\hline RMSEA & 0,052 & $\leq 0,08$ & Fit \\
\hline RMR & 0.061 & $\leq 0,05$ & Not fit \\
\hline Comparative Fit Index (CFI) & 0,932 & $\geq 0,9$ & Fit \\
\hline Tucker-Lewis Index (TLI) & 0,928 & $\geq 0,9$ & Fit \\
\hline NFI & 0,829 & $\geq 0,9$ & Not fit \\
\hline
\end{tabular}

Source: Output SPSS AMOS 20 
The Role of Human Resource Quality in Mediating Human Resource Management, Information Technology and Organisational Culture on Employee Performance: A Study on Indonesian E-Commerce Industry

Based on the table of the goodness of fit can be seen that the value of goodness of fit structural stage produces model criteria that can be said to be fit. According to Solimun (2002) and Hair et al. (2014), if there is at least one criterion in the structural model that meets the goodness of fit criteria, the model can be fit. This research model has a value of RMSEA $<0.08$, which is 0.052 . It suggests that errors in this research model are acceptable, with an estimated error of 5.2\%. Besides, the CFI, NFI and TLI values are also greater than 0.90 . It suggests that this research model may reflect actual sample data. Thus, this research model can be used.

\subsection{Hypothesis}

The next stage is a hypothesis test by looking at the results of the regression weights test, to find out whether or not the influence between one variable and another variable contained in the model can be done by observing the critical ratio (CR) value and its probability value (Ferdinand, 2002). A variable can be said to significantly affect other variables if the probability value is $\leq 0.05$ and the $C R$ value is $>1.96$ if it is positive and $<-1.96$ if it is negative.

Table3. Hypothesis Test

\begin{tabular}{|l|l|l|l|l|l|l|}
\hline H & Relationship between variable & Loading Factor (Std. reg w.) & C.R. & P \\
\hline H1 & HRQ & $<---$ & HRM & 0.331 & 5.261 & $* * *$ \\
\hline H2 & HRQ & $<---$ & IT & 0.353 & 4.076 & $* * *$ \\
\hline H3 & HRQ & $<---$ & OC & 0.286 & 2.790 & 0.005 \\
\hline H4 & EP & $<---$ & HRQ & 0.334 & 3.706 & $* * *$ \\
\hline H5 & EP & $<---$ & HRM & 0.197 & 3.097 & 0.002 \\
\hline H6 & EP & $<---$ & OC & 0.181 & 2.124 & 0.034 \\
\hline
\end{tabular}

Source: Output SPSSAMOS 20

Based on table 3, it can be concluded that the results of hypothesis testing in this study are as follows:

\section{Hypothesis 1: HRM has a significant influence on the quality of human resources.}

The result of the parameter influence of HRM variable on human resource quality showed significant results with a significance value of $0.000(\mathrm{p}<0.05)$ and C.R value of 1.96 of 5,261. The influence of HRM on human resources qualitypositively affectsa regression weight value of 0.357 . Based on this, it can be concluded that the hypothesis that $H R M$ has a significant influence on the quality of human resources is acceptable.

To maintain and improve the quality of good software engineers, HRM functions of the e-commerce industry must run well, starting from the first function of procurement of training and development for software engineers both in terms of hard or technical skills and soft skills so that their competence can continue to improve over time. The second function is to create an attractive compensation system for software engineers so that companies can compete in recruiting software engineers who are in the job market and maintain software engineers who have joined the company. The third function is to have a performance-based system assessment (appraisal system) so that the software engineers will always provide the best for their capabilities for the company. The fourth function is to provide a career level system in the company to create employee retention so that software engineers will also feel their career can continue to grow if working in the e-commerce industry. The fifth function is that the HR division has a transparent selection process and a valid measuring instrument so that the human resources who join the company are the best. The sixth function is that the HR division creates a career-level scheme that appeals to software engineers to continue to be motivated in their work. The seventh function creates a working atmosphere that involves employee participation, such as making a decision or suggestions for the development of the company that is certainly adjusted to each's portion and capacity. It can also increase employee engagement and a high sense of belonging by employees to their company. The eighth function is that the company has a clear description of duties and responsibilities to feel the company has a transparent measure in providing performance assessment in each division.

The resultis supported by (Alsabbah and Ibrahim 2014; Esch 2016, Darvish et al. 2017), which state that HRM can improve human resources quality both from hard and soft competency. HR managers should pay attention to all functions in HRM, ranging from compensation systems, training and 
The Role of Human Resource Quality in Mediating Human Resource Management, Information Technology and Organisational Culture on Employee Performance: A Study on Indonesian E-Commerce Industry

training, performance assessment systems, employee retention programs, employee selection, career planning, employee participation to clear definitions of work so that the quality of human resources in the e-commerce industry can be improved.

\section{Hypothesis 2: information technology has a significant influence on the quality of human resources.}

The result of the parameter influence of information technology variables on human resources quality showed significant results with a significance value of $0.000(\mathrm{p}<0.05)$ and a C.R. value of 1.96 of 4,076. The influence of information technology on human resources quality positively affects $a$ regression weight value of 0.355 . Based on this, it can be concluded that the hypothesis that states that information technology has a significant influence on human resource quality is acceptable.

The result indicates that an e-commerce company needs to provide adequate IT infrastructure, both software and hardware. Because of the excellent integration between the software and hardware used will be able to produce maximum output. The selected technology must also meet several factors, namely ease of use, minimal risk, and following the needs so that the implementation can produce a maximal output.

It is supported by (Parry and Battista 2019; Wicaksono 2018; Bahador 2017), which states that information technology affects human resources quality.The development of information technology encourages employees to continue to improve their skills in utilising existing technology and the availability of technology to facilitate employees in completing repetitive work so that they can focus more on honing their skills in analysing data. Especially in the e-commerce industry, technology such as artificial intelligence helps humans conduct big data analysis to study consumer behaviour to strategic business decision making. Of course, this technology can run if the availability of hardware, adequate software and qualified human resources quality. Thus, it can be concluded that the availability of information technology ranging from the availability of platforms, data and applications, the ease of the system, minimising risks, and increasing the trust of the system, affects the quality of human resources.

\section{Hypothesis 3: organisational culture has a significant influence on the quality of human resources.}

The results of the organisation's cultural variable influence on the quality of human resources showed significant results with a significance value of $0.005(\mathrm{p}<0.05)$ and a C.R. value of 1.96 of 2.79 . The influence of organisational culture on the quality of human resources positively affects a regression weight of 0.251 . Based on this, it can be concluded that the hypothesis that the culture of the organisation has a significant influence on the quality of human resources is acceptable.

As a rapidly growing industry, a considerable level of dependence on technology, a reasonably fast technology life cycle and a focus on customers certainly make e-commerce companies must be able to adapt to the environment. It can be done by building and creating a culture that aligns with the ecommerce industry's characteristics, which encourages employees not to stop innovating by providing opportunities, space, and trust as much as possible for employees to pour ideas and give advice. Also, it demands employees to work in detail to create a highly competitive advantage.

This study's results are supported by (Sungadi 2018; Symbolon 2015; Pope 2018), who stated that the organisation's culture affects the quality of human resources. Each industry has different characteristics and cultures, not least in the e-commerce industry. The number of e-commerce-based startup companies is multiplying. The E-commerce industry is an industry that is very closely related to technology. It is known that the development of technology is very massif and fast, so that it requires innovations and courage in risk-taking in order for organisations to be able to compete and survive when in the land of new disruptions.

The need for culture encourages members of the organisation. In this case, employees should be able to align themselves with the culture of the organisation. It can be concluded that aspects of organisational culture ranging from innovation, the courage to take risks, pay attention to detail, oriented to results, oriented to employees, team-oriented, aggressiveness, and stability affect human resources quality. 
The Role of Human Resource Quality in Mediating Human Resource Management, Information Technology and Organisational Culture on Employee Performance: A Study on Indonesian E-Commerce Industry

\section{Hypothesis 4: the quality of human resources has a significant influence on employee performance.}

The HR quality variable's parameter influence on employee performance showed significant results with significance value of $0.000(p<0.05)$ and a C.R value of 1.96 of 3,706. The influence of human resources quality on employee performance positively affectsa regression weight value of 0.392 . Based on this, it can be concluded that the hypothesis that the quality of human resources has a significant influence on employee performance is acceptable.

In terms of knowledge, skills and work experience, e-commerce companies must be able to have employees who have knowledge, skills and experience in standard software applications, programming language, easy interface design, database, network, and hardware so that by having these capabilities, employees will quickly adapt and work to the maximum in carrying out their duties and responsibilities as software engineers. While in terms of self-concept, employees must have the ability to communicate, interpersonal, management, cooperation, presentation, negotiation, facilitator and leadership. As a software engineer, communication with other divisions (end-user) is essential because end-user satisfaction is one of the most important benchmarks of a software engineer's performance. Having a variety of soft skills is crucial, in addition to technical capabilities.

This study is also supported by (Sarboini 2018; Martini et. al. 2016; Xu 2014; Sujiati et. al. 2017; Winarno 2015), which states the quality of human resources can improve employee performance, it can be concluded that the quality of human resources ranging from the aspects of knowledge, skills, nature and work experience is essential to be a concern to improve the performance of employees in the e-commerce industry.

\section{Hypothesis 5: HRMhas a significant influence on employee performance.}

The result of the HR management variable's parameter effect on employee performance showed significant results with a significance value of $0.002(\mathrm{p}<0.05)$ and C.R value of 1.96 of 3,097 . The influence of HR management on employee performance has a positive effect on a regression weight of 0.250. Based on this, it can be concluded that the hypothesis that HR management has a significant influence on employee performance is acceptable.

HR functions consisting of training and development, compensation, assessment, retention, selection, career path, work atmosphere, task description, and responsibility have their respective roles in improving software engineers' performance. The function of training and development is by procuring training and development for software engineers to periodically hone and improve their hard skills and soft skills so that the resulting performance will be more maximal and productive. Compensation function is implementing a compensation system that is attractive to software engineers able to encourage employees to continue to provide the best performance and make them survive in the company for an extended period (loyal). Furthermore, the assessment function is to have a performance-based appraisal system so that the software engineers realise that the assessment is done based on performance instead of the leader's subjectivity. The employee will always give the best of his ability. The career level function is to provide a career path system in the company to create employee retention so that software engineers will also feel appreciated by the company by providing equal opportunities for them to improve their careers in this industry.

The selection function is that the HR division has a transparent selection process and valid measuring instruments so that employees realise that the company is objective in assessing its employees' performance. The career level function is the HR division to create a career path scheme that appeals to software engineers to continue to be motivated in working and produce optimal performance.HR division must create a work atmosphere that involves employee participation, such as making decisions or suggestions for company development, which is of course adjusted to their respective portions and capacities so that a high sense of belonging to the company will increase in employees so that the resulting performance is also maximised.The last function is that the company has a clear description of duties and responsibilities to feel the company has a transparent measure in providing performance assessment in each division. An attractive and fair compensation system implemented in e-commerce companies, starting from compensation, will encourage employees to give their best performance. 
The Role of Human Resource Quality in Mediating Human Resource Management, Information Technology and Organisational Culture on Employee Performance: A Study on Indonesian E-Commerce Industry

This study is also supported by previous studies (Mutua et al. 2017; Chukwuka and Nwakoby 2018; Hassan 2012; Tabouli 2016), which states that $\mathrm{hr}$ management functions can improve employee performance, it can be concluded that HR managers should pay attention to all functions in HRM ranging from compensation system, training and development, performance assessment system, retention, employee selection, career planning, employee participation to clear definition of work so that employee performance in the e-commerce industry can improve.

\section{Hypothesis 6: organisational culture has a significant influence on employee performance.}

The organisation's cultural variable impact on employee performance showed significant results with a significance value of $0.034(\mathrm{p}<0.05)$ and a C.R. value of 1.96 of 2,124 . The influence of organisational culture on employee performance has a positive effect on a regression weight of 0.187 . Based on this, it can be concluded that the hypothesis that the culture of the organisation has a significant influence on the performance of employees is acceptable.

It shows that the values instilled in employees such as NAKAMA in Tokopedia, $5 \mathrm{~W}$ in shopee, and the values in Bukalapak, Blibli and other e-commerce companies become very important in driving the performance of employees. Having positive values and oriented to the progress of employees and people makes employees feel working not only as a profession but also indirectly feel to contribute to the interests and more significant progress that is the wider society (society) so that the performance provided becomes more optimal.

The results of this study were also supported by previous studies (Paschal and Nizam 2016; Stephen and Stephen 2016; Supriadi 2018; Nasution et al. 2018), which states that organisational culture affects employee performance so that it can be concluded that aspects of organisational culture ranging from the culture of innovation, the courage to take risks, pay attention to detail, oriented to results, oriented to employees, team-oriented, aggressiveness and stability affect employee performance.

\section{Hypothesis 7: HRM has a significant indirect influence on employee performance through the quality of human resources.}

The influence of HRM variables on performance through human resources quality showed significant results where the value of $\mathrm{Z} 1$ is greater than 1.96 , which is 2.995 . It can be concluded that the hypothesis that HRM has a significant indirect influence on employee performance through the quality of human resources is acceptable.

This study's results are also supported by several previous researchers who said that hr management in a company is an important pillar and process in improving the performance and quality of human resources. HR management consisting of compensation, training and development, recruitment and performance improvement functions are essential elements in improving the quality or competence of employees in an organisation (Alsabbah\&Hazrillzwar, 2014). Haslinda (2009) explained that the implementation of good HR management can improve employees' ability in work, productivity, and efficiency and improve the external quality (output) of goods or services offered to consumers. Kehoe and Wright (2013) argue that HR management practices are a fundamental factor for employees to gain competencies that in turn, significantly improve organisational performance. Sung and Choi (2014) proposed that organisations design and implement HR management practices to work effectively and achieve performance expectations by improving individual competencies or quality.

Similarly, Leuhery (2018) argues that human resources' quality has an essential role in an organisation. The higher the quality of human resources, the better the performance and performance. Therefore, based on the description, it can be concluded that HRM has an indirect influence on the performance of employee mediated by the quality of human resources.

\section{Hypothesis 8: information technology has a significant indirect influence on employee performance through human resources quality.}

The parameters of the influence of information technology variables on performance through human resources quality showed significant results where the value of $Z 1$ is greater than 1.96, which is 2,694. 
The Role of Human Resource Quality in Mediating Human Resource Management, Information Technology and Organisational Culture on Employee Performance: A Study on Indonesian E-Commerce Industry

It can be concluded that the hypothesis that information technology has a significant indirect influence on employee performance through the quality of human resources is acceptable.

This study supports the results of previous research that explains that the rapid development of information technology over time has provided convenience for human life in carrying out its daily activities both as professionals and business people. With the ease obtained, it also encourages most people to adopt the latest technology. Bahador et al. (2012) said that the development of information technology indirectly forces professional accountants to improve their skills to do their job better. In addition to being used individually, various organisations have also used technology to improve their employees' performance and productivity. Parry and Battista (2019) explained that organisations had used the latest technologies, such as artificial intelligence and robotics, to automate repetitive work and make complex, fast and accurate decisions through prediction algorithms. Therefore, based on the description and the results of the analysis in this study, it can be concluded that there is an indirect influence between information technology on employee performance through the quality of human resources.

\section{Hypothesis 9: organisational culture has a significant indirect influence on employee performance through human resources quality.}

The parameters of the influence of information technology variables on performance through human resource quality showed significant results where the value of $\mathrm{Z1}$ is greater than 1.96, i.e. 2.187. It can be concluded that the hypothesis that information technology has a significant indirect influence on employee performance through the quality of human resources is acceptable.

This study's results are also supported by several previous researchers who conveyed that an organisation's success indeed can not be separated from how the organisation can build and create a positive culture (norms, values, habits) in the organisation. Organisational culture is undoubtedly formed by mutual agreement (stakeholders) tailored to its characteristics and objectives. E-commerce as an industry that is very attached to technology has innovative organisation characteristics, thinking big, teamwork, problem-solving, integrity, and customer-focused. The organisation's culture that has been mutually agreed upon following needs to be known understood, and embedded into all organisation members (employees) to achieve what the organisation expects (vision, mission and objectives). Establishing positive organisational values or culture will certainly encourage its members to continue developing their qualities. Sungadi (2018) and The Pope (2018) explained that there is a significant influence between the organisation's culture on improving competence and quality of employees.

In addition to impacting the quality of human resources, organisational culture can also encourage employee performance. By knowing, understanding, and living the organisation's values, members of the organisation or employees will be able to clearly understand the objectives of the organisation so that they will be encouraged to improve their performance. Wambugu (2014) argues that an organisation with a culture that can adapt to dynamic changes and meet the expectations and satisfaction of its employees will have a positive impact on its performance. Awadh and Saad (2013) explained that employee performance could improve with establishing a strong organisational culture. Therefore, based on the description, it can be concluded that the organisation's culture has an indirect influence on employee performance mediated by the quality of human resources.

\section{CONCLUSION}

Regarding thestudy results, it concludesthat:

1. There is a significant influence between HRM and the quality of human resources in the ecommerce industry.

2. There is a significant influence between information technology and the quality of human resources in the e-commerce industry.

3. There is a significant influence between organisational culture and the quality of human resources in the e-commerce industry.

4. There is a significant influence between HRM and employee performance in the e-commerce industry. 
The Role of Human Resource Quality in Mediating Human Resource Management, Information Technology and Organisational Culture on Employee Performance: A Study on Indonesian E-Commerce Industry

5. There is a significant influence between the quality of human resources and employees' performance in the e-commerce industry.

6. There is a significant influence between organisational culture and employee performance in the e-commerce industry.

7. There is an indirect influence between HRM management and performance through the quality of human resources.

8. There is an indirect influence between information technology and performance through the quality of human resources.

9. There is an indirect influence between organisational culture and performance through the quality of human resources.

\section{SUGGESTION}

Based on the conclusions and statistical results, the researcher can provide several suggestions, as follows:

1. The statistical results show that the HRM variable has the greatest influence on the performance of software engineers. The HRM variable dimensions that have the most dominant influence are employee retention, selection, and participation, which means that companies must prioritise the principles of fairness, transparency, and openness in treating employees. It is also in line with the demographics of employees, many of whom come from the millennial generation (born in 19811996) and generation Z (1997-2012), who always want to develop and express their creativity. Based on the descriptive results, all functions are running well. However, things can still be improved, such as in the appraisal system dimension, namely the satisfaction with the company's performance appraisal system. In this, the researcher suggests that the assessment system can be made more transparent and include feedback so that employees are more aware of what needs to be improved and developed by the employee. Meanwhile, on the dimension of selection, companies are advised to use valid measuring instruments in recruiting, transferring, and promoting their employees so that the elements of objectivity and transparency are even more real. In the dimension of participation, based on the results of descriptive data analysis, the researcher suggests that the company, through its leadership, must be able to involve employees' participation when making certain decisions, so that a sense of belonging (sense of belonging) to employees will be better.

2. Based on statistical results, it shows that information technology influences the quality of human resources. The dimensions of information technology variables that have a dominant influence on human resources quality are the network platform, trust, and risk. Based on descriptive data, it shows that all components of information technology are running well, however, there is still something that can be improved. Companies are advised to increase network speed connectivity (wired / wireless) and connectivity coverage (coverage area) so that business processes can run even more smoothly on the network platform dimension. In the dimension of company trust, it is advisable to continue to support employees by procuring technologies that can make employees even more productive. Meanwhile, in the risk dimension, the company is advised to accommodate employees with technologies that can minimise risks in carrying out work. The technology developed and used by the company must be easy to operate (user friendly) so that it directly impacts employee productivity and performance in a better direction.

3. Based on statistical results, it shows that organisational culture directly influences the performance of software engineers. The dimensions of the organisational culture variable that have the most dominant influence are aggressiveness, stability and attention to detail, which means that as an industry that is closely related to technological developments, it is essential to make all members of the organisation continue to be aggressive and stable in providing their performance so that the organisation can always be competitive, agile in facing the changes. In addition, it is in line with the profession of a software engineer that is always required to be careful and thorough in working so that a culture of attention to detail becomes very important to support the success of a software engineer to achieve his best performance. 
The Role of Human Resource Quality in Mediating Human Resource Management, Information Technology and Organisational Culture on Employee Performance: A Study on Indonesian E-Commerce Industry

4. Based on statistical results, it shows that the quality of human resources influencessoftware engineers' performance. The dimensions of human resources quality variables that have a dominant influence are work experience and knowledge. Based on descriptive data, it shows that all components of human resources' quality have been running well. However, there are still things that can be improved. In the dimension of company work experience, e-commerce companies are advised to do balanced recruitment between the knowledge and experience possessed by their employees so that employees can adapt quickly to their responsibilities so that the performance given can be maximised whereas, in the knowledge dimension, the company is expected to provide regular training and development following the latest needs so that the knowledge of software engineers is more up to date and can encourage their performance to go up even more.

\section{REFERENCES}

[1] Abdoulaye. (2018). Research on the Relationship between Human Resource Management Practices and Employee Retention in Chinese Overseas Enterprise Evidence from Huawei in Senegal. Journal of International Business Research and Marketing, 7-22.

[2] Ahmed, F., Capretz, L. F., Bouktif, S., \& Campbell, P. (2013). Soft Skills and Software Development: A Reflection from Software Industry. International Journal of Information Processing and Management, 171-191.

[3] Alfiyah, S. E. (2016). Motivasi Kerja, Loyalitas, dan Kualitas Karyawan Terhadap Kinerja Karyawan PT. Varia Usaha Gresik. BISMA, 144-155.

[4] Alsabbah, M. Y., \& Hazrillzwar, I. (2014). HRM Practices and Employee Competence: A General System Perspective. International Journal of Business, Economics and Law, 11-17.

[5] Ayangbekun, O. J., \& Olowookere, A. S. (2014). ICT Application To Human Resource Management System Design. Journal of Multidisciplinary Engineering Science and Technology, 237-280.

[6] Badeni. (2013). Kepemimpinan dan Prilaku Organisasi. Bandung: Alfabeta.

[7] Bahador, K., Maisurah, K., \& Haider, A. (2012). Information Technology Skills and Competencies - A Case for Professional Accountants . Lecture Notes in Business Information Processing, 81-87.

[8] Bangun, W. (2018). Manajemen Sumber Daya Manusia. Jakarta: Erlangga.

[9] Chouhan, V. S., \& Srivastava, S. (2014). Understanding Competencies and Competency Modeling - A Literature Survey. IOSR Journal of Business and Management, 14-22.

[10] Chukwuka, E. J., \& Nwakoby, N. P. (2018). Effect of Human Resource Management Practices on Employee Retention and Performance in Nigerian Insurance Industry. World Journal of Research and Review, 27-41.

[11] Darvish, H., Moogali, A., Moosavi, M., \& Panahi, B. (2012). Survey Relationship between Human Resources Roles and Human Resources Competencies. International Journal of Academic Research in Business and Social Sciences, 254-256.

[12] Dessler, G. (2017). Human Resources Management 15th Edition. Florida: Pearson.

[13] Diamantidis, A. D., \& Chatzoglou, P. (2018). Factors affecting employee performance: an empirical approach. International Journal of Productivity and Performance Management, 1-24.

[14] Elhazzam, M. (2015). The Effect of ICT on Human Resources Management Practices. International Journal of Innovative Research in Engineering \& Management (IJIREM), 35-38.

[15] Esch, E. V., Wei, L. Q., \& Chiang, F. F. (2017). High-performance human resource practicesand firm performance: the mediating role of employees' competencies and the moderating roleof climate for creativity. The International Journal of Human ResourceManagement, 1-26.

[16] Fahmi, I. (2013). Perilaku Organisasi. Bandung: Alfabeta.

[17] Ferdinand. (2002). Metode Penelitian Manajemen : Pedoman Penelitian untuk Skripsi, Tesis, dan Desertasi Ilmu Manajemen. Semarang: Badan.

[18] Hair, J. F., Black, W. C., Babin, B. J., \& Anderson, R. E. (2014). Multivariate Data Analysis. Harlow: Pearson. 
The Role of Human Resource Quality in Mediating Human Resource Management, Information Technology and Organisational Culture on Employee Performance: A Study on Indonesian E-Commerce Industry

[19] Hair, J. F., Hult, G. T., Ringle, C., \& Sarstedt, M. (2014). A Primer on Partial Least Square Structural Equation Modeling (SEM-PLS). California: SAGE.

[20] Hasibuan, M. S. (2016). Manajemen Sumber Daya Manusia. Jakarta: PT Bumi Aksara.

[21] Haslinda, A. (2009). Outcomes of Human Resource Development Interventions. Journal of Social Sciences, 25-32.

[22] Hassan, S. (2016). Impact of HRM Practices on Employee's Performance. International Journal of Academic Research in Accounting, Finance and Management Science, 15-22.

[23] Hee, O. C., \& Jing, K. R. (2018). The Influence of Human Resource Management Practices on Employee Performance in the Manufacturing Sector in Malaysia. International Journal of Human Resource Studies, 129-147.

[24] Hong, E. N., Hao, L. Z., Kumar, R., Ramendran, C., \& Kadiresan, V. (2012). An Effectiveness of Human Resource Management Practices on Employee Retention in Institute of Higher learning: - A Regression Analysis. International Journal of Business Research and Management , 60-79.

[25] Kadir, A. (2014). Pengenalan Sistem Informasi Edisi Revisi. Yogyakarta: Andi.

[26] Kehoe, R. R., \& Wright, P. M. (2013). The Impact of High-Performance Human Resource Practices on Employees' Attitudes and Behaviors. Journal of Management, 366-391.

[27] Makulova, A. T., Alimzhanova, G. M., Bekturganova, Z. M., Umirzakova, Z. A., Makulova, L. T., \& Karymbayeva, K. M. (2015). Theory and Practice of Competency-Based Approach in Education. International Education Studies, 183-192.

[28] Mangkunegara, A. P. (2015). Manajemen Sumber Daya Manusia Perusahaan. Bandung: Remaja Rosdakarya.

[29] Martini, I. A., Rahyuda, I. K., Sintaasih, D. K., \& Piartrini, P. S. (2018). The Influence of Competency on Employee Performance through Organizational Commitment Dimension. Journal of Business and Management, 29-37.

[30] Marwat, Z. A., Qureshi, T. M., \& Ramay, M. I. (2006). Impact of Human Resource Management on Employee Performance: A Case of Paskitani Telecom Sector. Muhammad Ali Jinnah University Islamabad.

[31] Mathis, R. L., Jackson, J. H., Valentine, S. R., \& Meglich, P. (2016). Human Resource Management. Boston: Cengage.

[32] Mulyana, A. Z. (2010). Rahasia Menjadi Guru Hebat. Jakarta: Grasindo.

[33] Mutua, J. M., Kinyili, J., \& Arasa, R. (2017). Assessing The Influence of Human Resource Management Practices on Employee Performance In The Health Sector In Machakos County, Kenya. International Journal of Economics, Commerce and Management, 282-322.

[34] Nasution, F. N., Mariatin, E., \& Zahreni, S. (2018). The Influence of Career Development and Organizational Culture on Employee Performance. International Journal of Scientific Research and Management, 57-65.

[35] Parry, E., \& Battista, V. (2019). The Impact of Emerging Technologies on Work: A Review of Evidence and Implications for The Human Resource Function. Emerald Open Research, 1-13.

[36] Paschal, A. O., \& Nizam, I. (2016). Effects of Organisational Culture on Employees Performance: Case of Singapore Telecommunication. International Journal of Accounting \& Business Management, 19-26.

[37] Patacsil, F. F., \& Tablatin, C. L. (2017). Exploring The Importance of Soft and Hard Skills as Perceived by IT Internship Students and Industry: A Gap Analysis. Journal of Technology and Science Education, 347-368.

[38] Paus, J. R. (2019). Analysis of Organizational Culture on Competency of Educators Community Learning Activities Center (PKBM) In Minahasa District. International Conference of Primary Education Research Pivotal Literature and Research UNNES 2018 (pp. 252-254). Manado: Atlantis Press. 
The Role of Human Resource Quality in Mediating Human Resource Management, Information Technology and Organisational Culture on Employee Performance: A Study on Indonesian E-Commerce Industry

[39] Rahadian, L. (2019, Agustus 6). https://ekonomi.bisnis.com. Retrieved from https://ekonomi. bisnis.com:https://ekonomi.bisnis.com/read/20190806/12/1132979/mencari-cara-kerek-kualitassdm-di-era-revolusi-industri-40

[40] Rahmi, B. M. (2014). Pengaruh Kepemimpinan Transformasional Terhadap Organizational Citizenship Behavior dan Komitmen Organisasi Dengan Mediasi Kepuasan Kerja. E-Jurnal Manajemen Unud, 330-350.

[41] Ravichandran, T., \& Lertwongsatien, C. (2005). Effect of Information Systems Resources and Capabilities on Firm Performance: A Resource-Based Perspective. Journal of Management Information Systems, 237-276.

[42] Raymond, C. P., Hatane, S., \& Hutabarat, J. (2015). Analisis Kualitas Sumber Daya Manusia, Kualitas Pelayanan, Kinerja Organisasi, Kepercayaan Masyarakat dan Kepuasan Masyarakat (Studi Kasus: Dinas Kependudukan dan Catatan Sipil Kabupaten Nabire). Jurnal Teknologi dan Manajemen Industri, 1-8.

[43] Robbins, S. P., \& Judge, T. A. (2015). Organizational Behavior, 16th Edition. San Diego: Pearson.

[44] Rumasukun, S. F., Rante, Y., Wambrauw, O. O., \& Bharanti, B. E. (2015). The Influence of Human Resource Management Strategy and Competence on Employee Performance with the Mediation of Work Motivation, Organizational Commitment and Work Culture. International Journal of Business and Management Invention, 15-27.

[45] Sarboini, Rizal, S., Surya, J., \& Yusuf, Z. (2018). The Effect of Leadership, Compensation and Competency on Employee Performance. Jurnal Ilmiah Peuradeun, 215-234.

[46] Shaukat, H., Ashraf, N., \& Ghafoor, S. (2015). Impact of Human Resource Management Practices on Employee Performance. Middle-East Journal of Scientific Research, 329-338.

[47] Simbolon, B. (2017). Hubungan Budaya Organisasi dan Motivasi dengan Kinerja Guru di Sekolah Yayasan Santo Antonius Jakarta. Jurnal Manajemen Pendidikan, 116-138.

[48] Simbolon, C. Y. (2015). Pengaruh Budaya Organisasi dan Pelatihan Terhadap Kinerja Pegawai di Sekretariat Daerah Kabupaten Samosir. Jakarta: Universitas Terbuka.

[49] Sleekr. (2019, Mei 3). https://sleekr.co/job_desc/programmer/. Retrieved from https://sleekr.co: https://sleekr.co/job_desc/programmer/

[50] Soegoto, E. S. (2014). Entrepreneurship Menjadi Pebisnis Ulung. Jakarta: Elex Media Komputindo.

[51] Solimun. (2002). Structural Equation Modeling LISREL dan AMOS. Malang: Fakultas MIPA Universitas Brawijaya.

[52] Spencer, L. M., \& Spencer, S. M. (2008). Competence at Work Model for Superior Performance. Michigan: WIley.

[53] Stephen, E. N., \& Stephen, E. A. (2016). Organizational Culture and Its Impact on Employee Performance and Job Satisfaction: A Case Study of Niger Delta University, Amassoma. Higher Education of Social Science, 36-45.

[54] Subair, M. (2008, Agustus 21). http://bair.web.ugm.ac.id. Retrieved from http://bair.web.ugm.ac.id:http://bair.web.ugm.ac.id/Strategi_Pemanfaatan_TI_untuk_Meningkatk an_Kualitas_Layanan_PNRI.htm

[55] Sujiati, Ma'arif, M. S., \& Najib, M. (2017). The Effect of Motivation and Competence on Employee Performance in Satellite Technology Center - National Institute Aeronautics and Space. Jurnal Aplikasi Manajemen, 229-237.

[56] Sung, S. Y., \& Choi, J. N. (2014). Multiple Dimensions of Human Resource Development and Organizational Performance. Journal of Organizational Behavior, 851-870.

[57] Sungadi. (2018). Pengaruh Budaya Organisasi terhadap Kompetensi Pustakawan (Studi Kasus pada Universitas Islam Indonesia Yogyakarta). Journal of Library and Information Science, 71118. 
The Role of Human Resource Quality in Mediating Human Resource Management, Information Technology and Organisational Culture on Employee Performance: A Study on Indonesian E-Commerce Industry

[58] Sunhaji. (2014). Kualitas Sumber Daya Manusia (Kualifikasi, Kompetensi dan Sertifikasi Guru). Jurnal Kependidikan IAIN , 142-160.

[59] Supriadi, A. D., Suharto, \& Sodikin. (2018). The Effect of Competence and Organization Culture to Employee Performance With Motivation as The Mediation Variable in The Directorate General of Fiscal Balance-Ministry of Finance, Indonesia. Jurnal Perspektif Pembiayaan Dan Pembangunan Daerah, 325-336.

[60] Sutarman. (2012). Pengantar Teknologi Informasi. Jakarta: PT. Bumi Aksara.

[61] Tabouli, E. M., Habtoor, N. A., \& Nashief S., M. (2016). The Impact of Human Resources Management on Employee. Asian Social Science, 176-192.

[62] Wambugu, L. W. (2014). Effects of Organizational Culture on Employee Performance. European Journal of Business and Management , 80-92.

[63] Wibowo. (2014). Manajemen Kinerja. Jakarta: Rajawali Press.

[64] Wibowo. (2016). Manajemen Kinerja. Jakarta: PT Raja Grafindo Persada.

[65] Wicaksono. (2018). Pengaruh Teknologi Informasi Terhadap Kinerja Karyawan Melalui Kompetensi di Koperasi Susus Warga Mulya Yogyakarta. Yogyakarta: UPN "Veteran" Yogyakarta.

[66] Winarno, A., \& Perdana, Y. (2015). The Effecs of Competence and Motivation on Employee Performance at PT Pos Indonesia Bandung Cilaki Head Office. nt'l Conference on Business, Marketing \& Information System Management, (pp. 1-5). Paris.

[67] Wirawan. (2015). Manajemen Sumber Daya Manusia Indonesia. Jakarta: PT Raja Grafindo Persada.

[68] Xu, A., \& Ye, L. (2014). Impacts of teachers' competency on job performance in research universities with industry characteristics: Taking academic atmosphere as moderator. Journal of Industrial Engineering and Management, 1283-1292.

[69] Zahra, A. (2013). ICT and HRM: Management Perceptions about the Changing Scenario. Proceedings of 3rd International Conference on Business Management (pp. 1-5). Lahore: University of Management and Technology.

[70] Zuraida, U., Gustomo, A., Bekti, R., \& Pangestu, A. B. (2017). The Impact of Human Resource Practices, Employee Quality andInnovation on Performance: An Analysis of Woven Fabric SMEs. International Journal of Applied Business and Economic Research, 283-291.

\section{AUTHOR's BIOGRAPHY}

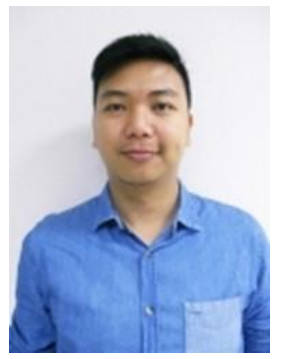

Dr. William Widjaja, is a lecturer in retail and business management program in Pradita University, Tangerang, Indonesia. He earns Doctorate of Economics, majoring in Human Resource Management from Pancasila University, Jakarta, Indonesia. His research discusses the role or human resource quality in moderating human resource management, information technology and organisational culture on employee performance in Indonesian e-commerce industry.

Citation: William Widjaja, et.al, "The Role of Human Resource Quality in Mediating Human Resource Management, Information Technology and Organisational Culture on Employee Performance: A Study on Indonesian E-Commerce Industry" International Journal of Managerial Studies and Research (IJMSR), vol 9, no.43, 2021, pp. 8-23. doi: https://doi.org/10.20431/2349-0349.0904002

Copyright: (c) 2021 Authors. This is an open-access article distributed under the terms of the Creative Commons Attribution License, which permits unrestricted use, distribution, and reproduction in any medium, provided the original author and source are credited. 